\title{
Exchange rate volatility and exports: a firm-level analysis
}

\section{Mehmet Nihat Solakoglu , Ebru Güven Solakoglu \& Tunç Demirağ}

To cite this article: Mehmet Nihat Solakoglu , Ebru Güven Solakoglu \& Tunç Demirağ (2008) Exchange rate volatility and exports: a firm-level analysis, Applied Economics, 40:7, 921-929, DOI: $10.1080 / 00036840600749888$

To link to this article: http://dx.doi.org/10.1080/00036840600749888

\section{1.}

Submit your article to this journal $\pi$

Џll Article views: 265

Q View related articles $\sqsubset$

Citing articles: 10 View citing articles 주 


\title{
Exchange rate volatility and exports: a firm-level analysis
}

\author{
Mehmet Nihat Solakoglu ${ }^{\mathrm{a}, *}$, Ebru Güven Solakoglu ${ }^{\mathrm{a}}$ and \\ Tunç Demira $\breve{g}^{\mathrm{b}}$ \\ ${ }^{a}$ Department of Banking and Finance, Bilkent University, Bilkent, Ankara, \\ 06800, Turkey \\ ${ }^{\mathrm{b}}$ Department of Management, Fatih University, Büyükçekmece, İstanbul, \\ 34500, Turkey
}

The relationship between real exports and exchange rate volatility is investigated using panel data analysis at the firm level. Results indicate that there is no negative or positive relationship between volatility and real exports. In addition, firm size and level of international activity do not influence the size and significance of the volatility effect on exports. However, there is some evidence that firms use import revenue to lower their exchange rate exposure.

\section{Introduction}

Is exchange rate risk detrimental to the flow of goods between countries? After the widespread move from fixed to floating exchange rate regimes, this question has been addressed many times both theoretically and empirically, and has led to a wide literature investigating the relationship between exchange rate risk and trade flows.

The effect of price uncertainty on the firm's production decisions is investigated starting in the early 70 s. The results of this research indicated that a perfectly competitive firm under price uncertainty produces less than it would produce under certainty. Furthermore, it was shown that a mean-preserving increase in the uncertainty decreases output even further, ceteris paribus (Baron (1970), Sandmo (1971)). This result has been used as the main theoretical justification for the impact of exchange rate risk on trade volumes. ${ }^{1}$ The works of Clark (1973), Ethier (1973), Hooper and Kohlhagen (1978) and Cushman (1986) provided some support for the aforementioned theoretical studies by finding a negative relationship between exchange rate risk and trade flows. More recent studies, however, provided conditions that lead to positive or ambiguous relationships between exchange rate risk and trade flows. The works of De Grauwe (1988), Giovannini (1988), Franke (1991), Neumann (1995) and Doyle (2001) and are some examples that show positive relationships between trade flows and exchange rate risk can be obtained under certain conditions.

Clear support for the main hypothesis - that exchange rate volatility is detrimental to trade volumes - has not been provided by empirical studies. Furthermore, the lack of consensus on a theoretical framework has led to a diverse and sometimes

\footnotetext{
*Corresponding author. E-mail: nsolakoglu@bilkent.edu.tr

${ }^{1}$ The existence of a forward market to hedge currency risk separates this risk from the firm's trade decisions. When hedging is possible, all production and trade decisions are made on the basis of the forward exchange rate. This is known as the 'Separation Theorem'. For more details, see Ethier (1973), Baron (1976) or Kawai and Zilcha (1986) for the separation theorem in trade literature, and Holthausen (1979) in the theory of the firm.
} 
unwieldy empirical literature. ${ }^{2}$ Most of the empirical works investigates the relationship between exchange rate volatility and trade flows by considering aggregate or bilateral trade flows either at the country-level or at the industry level (e.g. Hooper and Kohlhagen (1978), Cushman (1986), Thursby and Thursby (1987), Klein (1990), Bahmani -Oskooee $(1991,2002)^{3}$, Assery and Peel (1991), Kumar and Dhawan (1991), Pozo (1992), Gagnon (1993), Grobar (1993), Hassan and Tufte (1998), Vergil (2002), Baum et al. (2004)).

This article also studies the relationship between exchange rate risk and trade flows. However, our approach differs from earlier studies in two ways. First, instead of using aggregate or bilateral trade flows at the industry or the country level, we investigate this relationship at the firm level. If there is a negative or a positive association between exchange rate volatility and trade flows, it would be easier to detect it statistically at a firm level rather than at a country or industry level. Second, we investigate the role of several firm-related factors' influence - such as (import/export) ratio as a naturalhedging tool and level of international activity - on this relationship. Furthermore, by selecting Turkey, a developing country with few hedging tools available only to the largest firms and with almost nonexisting hedging market, we are hoping to examine the role of firm size and indirectly industry structure on the volatility-trade flow relationship. ${ }^{4}$ Real exports are used as the trade flow measure in this analysis.

The remainder of the article is organized as follows. Section II discusses the model specification and data sources. Section III presents the estimation results. Finally, the last Section presents our main conclusions and suggestions for further research.

\section{Model Specification and Implementation}

Our analysis is performed using annual data at the firm level between the years 2001 and 2003. Firm level data is obtained from Istanbul Stock Exchange $e^{5}$ for 500 largest firms in Turkey. Only 143 of these firms are used in the analysis, because either they had international transactions or had nonmissing data for the analysis. ${ }^{6}$ Macro variables required for the analysis - consumer price index (CPI), gross domestic product (GDP) and unit price index for exports - are obtained from IMF's International Financial Statistics. Monthly exchange rate data are obtained from the Central Bank of Turkey.

Between 2001 and 2003, Turkish exports to top 10 trading partners were close to $60 \%$ of total exports. These trading partners were: Germany, USA, UK, Italy, France, Spain, Netherlands, the Russian Federation, Israel and Greece. About $46 \%$ of these transactions between Turkey and these countries involved three currencies: TL, Euro and US dollar. For the top 18 countries, $70 \%$ of international transactions in goods and services involved the same three currencies. Therefore, in proxying exchange rate risk, prices of US dollar and Euro in terms of Turkish Lira is used to calculate our volatility measure.

Our main hypothesis in this study argues that exchange rate volatility has a negative effect on exports. However, as indicated earlier, we try to answer three related questions defined in hypotheses $\mathrm{H}_{1}$ to $\mathrm{H}_{3}$.

$H_{1}$ : Higher the usage of natural-hedging, which is defined as value of imports over value of exports in a year, lower the impact of exchange rate volatility on exports.

$\mathrm{H}_{2}$ : Higher the share of export revenue in total revenues, higher the impact of exchange rate volatility on exports.

$\mathrm{H}_{3}$ : Higher the size of the firm, lower the impact of exchange rate volatility on exports.

Although there are many different specifications used in the literature to test the relationship between exchange rate volatility and trade, many studies focus on a general specification. In this study, we also follow this general specification and test the effect of

\footnotetext{
${ }^{2}$ By a lack of consensus, we mean that theoretical works do not clearly specify which variables should be included in the conditioning set, or the measure of volatility, or correct model specification. Solakoğlu (2000) investigates the robustness of this so-called relationship by using Extreme Bound Analysis of Leamer and Leonard (1983), Leamer (1985) and finds that it is not robust. In a simulation, Gagnon (1993) also shows that this effect is too small to be detected.

${ }^{3}$ Instead of using official exchange rates, Bahmani-Oskooee (2002) study utilizes black market exchange rates, which may be significantly different from official rates for developing countries, and finds adverse effects of exchange rate volatility on trade flows.

${ }^{4}$ Many of the Turkish firms are smaller compared to European countries. In addition, smaller-firms are mostly ownermanaged and they do not have access to personnel with required knowledge to hedge. It is also known that pricing strategy of these firms are based on costs plus a profit margin.

${ }_{6}^{5}$ www.ise.gov.tr

${ }^{6}$ About $87 \%$ of the firms are in manufacturing, and about $10 \%$ in construction industries. The remaining firms are operating in other industries.
} 
exchange rate volatility on trade flows by estimating the following equation.

$$
\begin{array}{r}
Q_{i t}=\mu+\mathbf{X}_{i t} \beta+\varepsilon_{i t}, \quad i=1, \ldots, 143 \\
\quad \text { and } t=2001,2002 \text { and } 2003
\end{array}
$$

In this equation, $Q_{i t}$ is the $\log$ of export volume for firm $i$ for year $t$. Export volume is calculated by dividing export values with the export unit price index. The vector $\mathbf{X}_{i t}$ includes a measure of economic activity in the importing country, ${ }^{7}$ a relative price measure expressed as the ratio of foreign to domestic prices, ${ }^{8}$ the bilateral exchange rates measured as the price of the US dollar and Euro in terms of local currency and a measure of volatility, all in natural logarithm. Exchange rate volatility is measured by the standard deviation of the monthly bilateral exchange rate in a particular year.

Estimations are undertaken by three related specifications. First specification includes only the volatility measure along with macro variables. Second specification includes an interaction between natural-hedge, which is called coverage ratio, and volatility measure. This ratio is calculated by dividing value of imports by value of exports in a given year for a particular firm. If the timing of receiving export revenue and paying out the import expenses are not totally inconsistent and both are in the same currency unit, then firms should be able to match expenses with receipts to a degree and lower their exposure to exchange rate risk. Given this argument, the coefficient on this interaction should be positive indicating that higher coverage ratio will cause the hypothesized negative effect of volatility to decrease. Furthermore, this might even lead to a positive relationship between higher volatility and exports if coverage ratio is above one. ${ }^{9}$ We expect coefficient on this interaction to provide evidence either to accept or reject the hypothesis $\mathrm{H}_{1}$. In the last specification, we consider the role of level of international activity, as indicated by hypothesis $\mathrm{H}_{2}$. Level of international activity is measured by the share of export revenue in total revenue for a particular firm. As Dominguez and Tesar (2001) discusses, one view implies that firms with higher level of international activity should be impacted more from exchange rate volatility as they depend heavily on foreign transactions. On the other hand, another view argues that these firms will have a higher incentive to hedge their risk and use the available tools if exists or are not prohibitively expensive. Given the almost nonexistent market to hedge exchange rate risk in Turkey, we expect first view to prevail. Thus, the coefficient on the interaction term should have a negative sign, indicating the positive influence on volatility as the level of international activity increases.

Table 1 presents estimation results for three different specifications with two different dependent variables. Along with export volume, we also used share of export revenue in total revenue as a dependent variable. Cushman (1986) argues that firms may shift their exports to a third country when volatility increases rather than decreasing their total exports volume. If this is the situation for firms in our sample, we might not observe a change in their export volume as a result of increased volatility. However, we expect to see a decline in the share of export revenue in total caused by lower prices received. ${ }^{10}$ Each specification shows results for least squares, fixed-effects and random-effects models. Dependent variables in this Table are the adjusted volume of exports or adjusted percent of export revenue, respectively. ${ }^{11}$

Specification 1 includes only volatility as an explanatory variable. ${ }^{12}$ Based on the insignificant coefficient estimate on Volatility variable, we can say that there is no relationship between exchange rate volatility and real exports, regardless of the dependent variable chosen. Specification 2 incorporates coverage level as an interaction. In this specification, as we discussed earlier, we intend to see whether volatility loses its importance for firms with high coverage ratio. In other words, we would like to see whether firms use import-to-export revenue ratio as a natural hedging strategy. In all specifications,

${ }^{7}$ GDP value of industrialized countries is used as a measure of economic activity in the importing country.

${ }^{8}$ In calculating the relative price measure, CPI for industrialized countries is used.

${ }^{9}$ If the coverage ratio is above one, it will indicate that the value of imports is larger than the value of exports. Firms who do not have access to other hedging tools will try to protect themselves by exporting more and lowering their exposure in the importing side.

${ }^{10}$ It can be argued that firms will first try to sell to the markets where they will maximize their profits. If they shift their export to another country, we may expect that the prices they receive for the goods sold should be either at most the same or lower.

${ }^{11}$ Given that relative price, income measure for importing countries and exchange rates do not change from firm-to-firm in our estimation period, it is impossible to include all in one equation. Therefore, our dependent variable is regressed individually on these variables and information that is not captured by them - the error term - is used as the dependent variable in the final equation. In a way, we are using a two-step estimation which leads to inefficiency, but not inconsistency.

${ }^{12}$ For the sake of brewity, we do not provide the coefficient estimates on constant(s) and on macro variables used in the first step of the estimation process. 


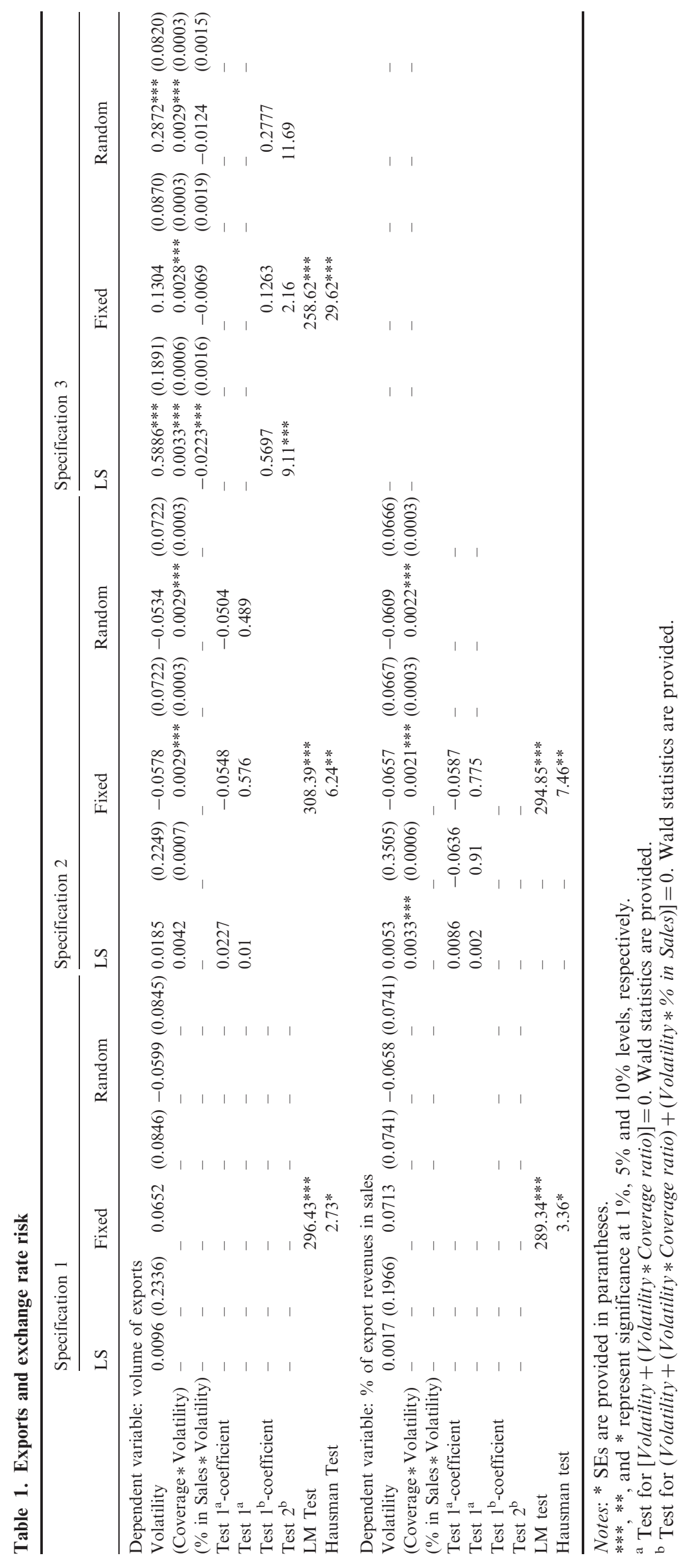


Lagrange Multiplier (LM) test indicates that GLS should be preferred over OLS. ${ }^{13}$ Moreover, high values of Hausman test statistics suggest that fixedeffects model, not random-effects model, should be used. ${ }^{14}$ Under the selected specification, coefficient of volatility variable is not significant. However, as implied by hypothesis $\mathrm{H}_{1}$, coverage interaction is positive and significant implying that higher the levels of coverage ratio lower the effect of volatility. However, the total effect (Volatility + (Volatility $*$ Coverage ratio)) is not significant.

In the last specification, we additionally include share of export revenue in total as an interaction (with volatility) variable to test for hypothesis $\mathrm{H}_{2}$. Based on LM and Hausman tests, fixed-effects model is the right model specification. As before, volatility does not seem to be important in affecting Turkish firms' export behaviour. The coefficient on this variable is statistically insignificant, while coverage interaction is still significant. Hence, results do not provide any evidence that shows the level of international activity has a magnifying influence on trade flow-volatility relationship. In our sample, about $30 \%$ of firms receive less than $10 \%$ of their revenue from exports, while only about $20 \%$ of the firms receive more than $50 \%$ of their revenues from exports. In addition, for more than $40 \%$ of the firms, coverage ratio is larger than $50 \%$, which might imply firms depend on natural hedge and ignore their exchange rate exposure as the level of international activity increases. However, for firms with higher dependence, the coverage ratio is lower. For example, for all firms in our sample, median coverage ratio is $73 \%$, while for firms with at least $50 \%$ of their revenue coming from exports, this ratio is about $40 \%$. Given this puzzling result, we need to look at the level of international activity and the coverage ratio in more detail in the analysis.

Table 2 shows estimation results for four sub-segments to examine the volatility-export relationship. Firms first segmented into two groups by coverage ratio: firms with lower usage of natural hedging - coverage ratio $<50 \%$ - and others.
Second, we grouped firms by the share of export revenue in total revenues. The mean of the share in our sample, which is $32 \%$, is used as the division point. Combining the two grouping variables, we obtain two-main segments and four-smaller segments as shown in Table 2. Main segments are, in a way, a replication of Table 1 and they do not provide different results as expected. On the other hand, we expect to see higher sensitivity to exchange rate volatility for firms with low coverage ratio and with high level of international activity. Nevertheless, our findings indicate that this is not the case. Given the segmentation scheme, we only use first specification in the estimations and the coefficient on volatility measure is insignificant in all segments.

As argued by Dominguez and Tesar (2001), size of the firm may also affect the level of exposure to exchange rate volatility. Larger firms may have higher level of international activity so they might have higher level of exposure to the risk. Alternatively, larger firms might have relevant resources to hedge their exposure which leads to lower sensitivity to exchange rate risk. With this expectation in mind, we created four segments of the firms in our sample by their size. To determine firm size, we used average number of employees over 2001-2003. ${ }^{15}$ It is also true for our sample that the level of international activity increases with size. Share of export revenue increases from about 24 to $40 \%$ from smallest to largest segment of firms. Interestingly, segment one, which includes the smallest firms in our sample, indicates that these firms have the highest coverage ratio and, at the median, their imports are almost equivalent to their exports in value.

We only present the results for third specification in Table $3 .{ }^{16}$ An interesting finding is the positive and significant volatility coefficient for segment 2 $(250<$ Emp $<501)$. In Table 3, in all segments, coverage and percent in sales interactions are significant with expected signs. However, the total effect is significant and positive only in segment 2 for random-effects model. It is also important to note

\footnotetext{
${ }^{13}$ High values of LM test favour GLS over OLS suggesting some exogenous factors, which may be correlated with the dependent variable and possibly omitted from the model, are not correlated with the right hand side variables which results inefficient OLS estimates whereas GLS gives efficient estimates.

${ }^{14}$ The null hypothesis states no correlation, thus large values of the Hausman's $X 2$ test suggest statistical preference for a fixed effects model specification. Fixed-effects estimation assumes that differences across firms can be captured by differences in the constant term. However, if the differences between firms are not just parametric shifts of the regression function, it may be more appropriate to view individual specific constant terms as randomly distributed across cross-sectional units with randomeffects model.

${ }^{15}$ Note that it would be better to use revenue to determine firm size. However, due to reporting problems in Turkey, these figures were not reliable. Each segment, in Table 3, approximately represents $25 \%$ of the firms.

${ }^{16}$ The most comprehensive specification is used in Table 3. Additionally, results from Tables 1 and 2 show that we can focus only on this specification without losing any important findings. Yet, we tried other two specifications and were not able to find any different results.
} 


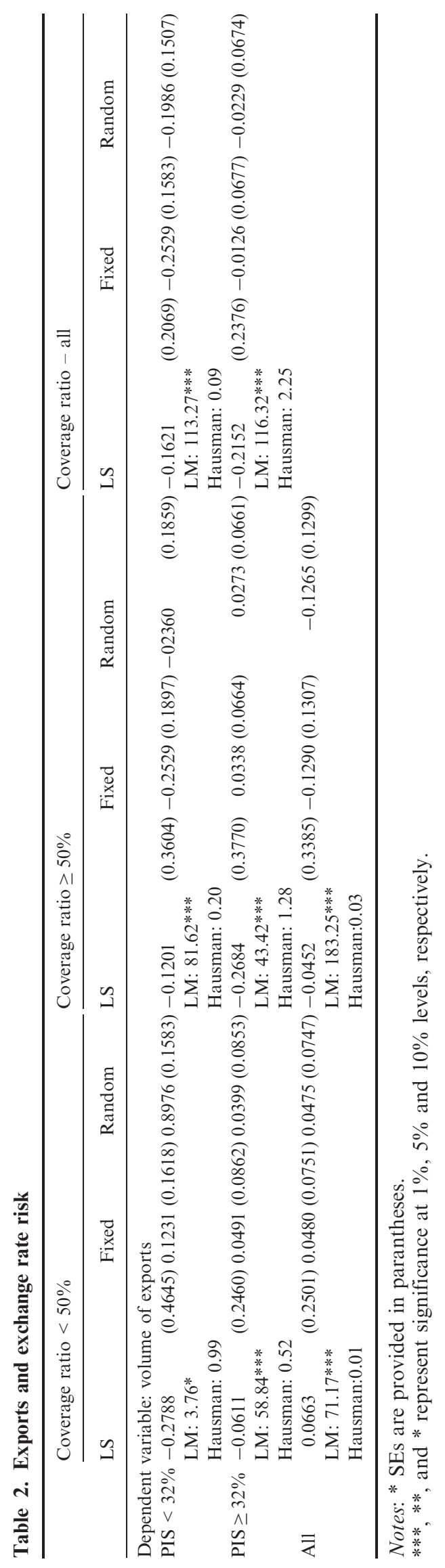




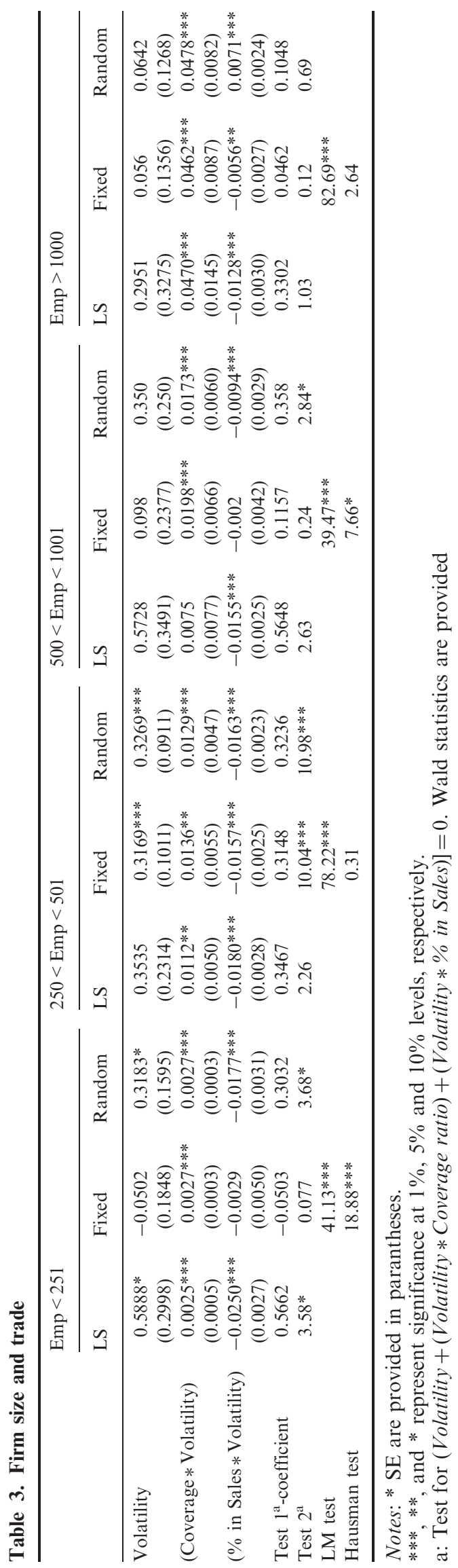


again that average share of export revenue is the smallest in segment 1 and the highest in segment 4 . This is also true for the size of the export volume. Export volume is 2.5 times more, on average, in segment 2 when compared to segment 1 . For segment 4 , this ratio is almost 25 times more when compared to segment 1 . Therefore, we can conclude that for segments 3 and 4 , the size of the export, as a volume or revenue, is large enough to cause firms to hedge. In addition, firms in segments 3 and 4 are large enough to have relevant resources at sufficient quantities to lower or eliminate exchange rate risk. ${ }^{17}$

As discussed in the literature, industry structure and competition can also be an important determinant of how volatility impacts trade flows. It can be argued that firms will not be able to pass along the additional cost, borne out by exchange rate risk, to the customers under a competitive environment. However, for noncompetitive industries, firms can shift some or all of this additional cost to customers by adjusting their sale prices. Given the size of the firms and destination countries for exports, we can assume that these firms are operating in competitive industries and do not have the flexibility to adjust their prices. However, our findings indicate that other than hedging through imports, these firms do not seem to pay close attention to exchange rate volatility. One possible reason may be the differences in the production and destination country environment which may lead firms to operate where prices are above marginal cost. If this is true, then firms can absorb modest changes in exchange rate risk to their prices.

\section{Concluding Remarks}

In this study, we examined the relationship between exchange rate volatility and real exports over the period 2001-2003. The analysis is conducted at the firm level rather than industry or country level. Given that Turkey, our sample country, does not have a well-established market to hedge exchange rate risk, we expect to capture any negative effect of exchange rate volatility on export volume. Moreover, the role of natural-hedging, through the ratio of import-toexport revenue, share of export revenue in total sales, and firm size on the aforementioned relationship are also investigated.

Results indicate that there is no adverse effect of exchange rate volatility on the export volume of firms. It appears that firms with high import-to-export revenue ratio are less concerned on the effect of exchange rate volatility on exports than the other firms. At the same time, level of international activity, as defined by share of export revenue, does not seem to be relevant in exporting decisions. Finally, size of the firm does not seem to have a significant affect on volatility-export relationship. Given the lack of a well-established market for hedging tools, it is surprising not to find a significant influence of volatility on exports. Based on the local-market environment, it will be important to examine the role of the market structure on the volatility-export relationship. Sensitivity of firms' trading decisions on volatility should be influenced significantly whether they are operating at a point where their price equals to their marginal cost or not. It is our intention to continue our efforts in this direction in our future work.

\section{References}

Assery, A. and Peel, D. A. (1991) The effects of exchange rate volatility on exports: some new estimates, Economics Letters, 37, 173-7.

Bahmani-Oskooee, M. (1991) Exchange rate uncertainty and trade flows of developing countries, The Journal of Developing Areas, 25, 497-508.

Bahmani-Oskooee, M. (2002) Does Black market exchange rate volatility deter the trade flows? iranian experience, Applied Economics, 34, 2249-55.

Baron, D. (1976) Flexible exchange rates, forward markets and the level of international trade, American Economic Review, 66, 253-66.

Baron, D. (1970) Price uncertainty, utility, and industry equilibrium, International Economic Review, 11, 463-80.

Baum, C. F., Çağlayan, M. and Ozkan, N. (2004) Nonlinear effects of exchange rate volatility on the volume of bilateral exports, Journal of Applied Econometrics, 19, 1-23.

Clark, P. B. (1973) Uncertainty, exchange risk, and the level of international trade, Western Economic Journal, 11, $302-13$.

Cushman, D. O. (1986) Has exchange risk depressed international trade? The impact of third country exchange risk, Journal of International Money and Finance, 5, 361-78.

De Grauwe, P. (1988) Exchange rate variability and the slowdown in growth of international trade, International Monetary Fund Staff Papers, 35, 63-84.

Dominguez, M. E. and Tesar, L. L. (2001) Trade and Exposure, The American Economic Review, Vol. 91, No. 2, Papers and Proceedings of the Hundred Thirteenth Annual Meeting of the AEA, 367-70.

${ }^{17}$ On average, firms in segment 1 and 4 have the lowest coverage ratios indicating that firms in segment 4 might be using other hedging tools more often than others. 
Doyle, E. (2001) Exchange rate volatility and Irish-UK trade, 1979-1992, Applied Economics, 33, 249-65.

Ethier, W. (1973) International trade and the forward exchange market, American Economic Review, 63, 494-503.

Franke, G. (1991) Exchange rate volatility and international trading strategy, Journal of International Money and Finance, 10, 292-307.

Gagnon, J. E. (1993) Exchange rate variability and the level of international trade, Journal of International Economics, 34, 269-87.

Giovannini, A. (1988) Exchange rates and traded goods prices, Journal of International Economics, 24, 317-30.

Grobar, L. M. (1993) The effect of real exchange rate uncertainty on ldc manufactured exports, Journal of Development Economics, 41, 367-76.

Hassan, M. K. and Tufte, D. R. (1998) Exchange rate volatility and aggregate export growth in Bangladesh, Applied Economics, 30, 189-201.

Holthausen, D. M. (1979) Hedging and the competitive firm under price uncertainty, American Economic Review, 69, 989-95.

Hooper, P. and Kohlhagen, S. W. (1978) The effect of exchange rate uncertainty on the prices and volume of international trade, Journal of International Economics, 8, 483-511.

Kawai, M. and Zilcha, I. (1986) International trade with forward-futures markets under exchange rate and price uncertainty, Journal of International Economics, 20, 83-98.
Klein, M. W. (1990) Sectoral effects of exchange rate volatility on united states exports, Journal of International Money and Finance, 9, 299-308.

Kumar, R. and Dhawan, R. (1991) Exchange rate volatility and Pakistan's exports to the developed world, 1974 1985, World Development, 19, 1225-40.

Leamer, E. and Leonard, H. (1983) Reporting the fragility of regression estimates, Review of Economics and Statistics, 65, 306-17.

Leamer, E.E. (1985) Sensitivity analyses would help, American Economic Review, 75, 308-13.

Neumann, M. (1995) Real effects of exchange rate volatility, Journal of International Money and Finance, 14, 417-26.

Pozo, S. (1992) Conditional exchange rate volatility and the volume of international trade: evidence from the early 1900s, The Review of Economics and Statistics, 74, $325-9$.

Sandmo, A. (1971) On the theory of the competitive firm under price uncertainty, American Economic Review, 61, 65-73.

Solakoglu, M. N. (2000) Exchange rate volatility and international trade: an empirical investigation, Ph.D. Thesis, North Carolina State University, 20-42.

Thursby, J.G. and Thursby, M.C. (1987) Bilateral trade flows, the linder hypothesis, and exchange risk, The Review of Economics and Statistics, 69, 488-95.

Vergil, H. (2002) Exchange rate volatility in turkey and its effect on trade flows, Journal of Economic and Social Research, 4, 83-99. 